Jasna Čapo

\section{Dva doma: hrvatska radna migracija u Njemačku kao transnacionalni fenomen}

Zagreb: Durieux, 2019, 412 str.

DOI: https://doi.org/10.11567/met.35.2.5

Knjiga Dva doma: hrvatska radna migracija u Njemačku kao transnacionalni fenomen rezultat je višegodišnjega autoričina istraživanja hrvatskih migranata i njihovih potomaka u Njemačkoj koje se oslanja na antropološke teorije migracija i etnografske metode istraživanja. Uz uvodno poglavlje »O knjizi« koje daje kratki pregled istraživanja radnih migracija u Njemačku, knjiga je strukturirana u osam poglavlja koja iznose temeljne postavke, kontekst i rezultate autoričina istraživanja uz dodatno, zaključno poglavlje koje sumira glavne nalaze.

U prvom poglavlju »Okolnosti i kontekst radnih migracija u Njemač$\mathrm{ku} \mathrm{u}$ drugoj polovici dvadesetog stoljeća« Jasna Ćapo na temelju postojeće literature pruža detaljan pregled društveno-političkih prilika u tadašnjoj Zapadnoj Njemačkoj i Jugoslaviji vezanih uz regrutaciju tzv. gostujućih radnika, odnosno »radnika na privremenom radu $\mathrm{u}$ inozemstvu«. $\mathrm{U}$ tom se kontekstu ističu bilateralni sporazumi koji su garantirali razne pogodnosti i prava radnim migrantima i članovima njihovih obitelji, uključujući elemente transnacionalne socijalne zaštite (Levitt i sur., 2016), unatoč općenitoj ambivalentnosti njemačke imigracijske politike koju opisuje autorica.

Nakon pregleda glavnih obilježja društvenoga i političkoga konteksta vezanog uz radne migracije $u$ obje ze- mlje, sljedeće se poglavlje pod naslovom »Znanstveni kontekst: promjenljive istraživačke paradigme« bavi osnovnim konceptima i pristupima migrantima $u$ Njemačkoj, ponajprije $u$ okviru Esserove (2000) teorije socijalne integracije i paradigme kulturne razlike, kao i studijama o integraciji hrvatskih migranata u Njemačkoj. Autorica iznosi i kritiku tih pristupa iz transnacionalne perspektive, uključujući razmatranje kritike metodološkog nacionalizma koja dovodi u pitanje kontejnerski model društva i pretpostavku o kulturnoj homogenosti nacionalnih zajednica. Posljednji dio poglavlja posvećen je opisu transnacionalne istraživačke paradigme i konceptu inkorporacije kao polazištima za autoričino istraživanje.

Treće poglavlje »O subjektima i istraživanju « donosi opis sociodemografskih karakteristika sugovornika i glavnih istraživačkih postupaka tijekom petnaest godina autoričina istraživanja u Njemačkoj te Zagrebu i Bosni i Hercegovini. Dijakronijska perspektiva istraživanja omogućila je Jasni Čapo bogat uvid u životne tijekove sedamdesetak migranata i njihovih potomaka (tj. »transnacionalnih generacija «) kroz više desetljeća, a u poglavljima koja slijede autorica obrađuje sljedeće glavne teme proizašle iz provedenih intervjua: planove povratka i mobilnost između Njemačke i Hrvatske/Bosne i Hercegovine, ulaganja $\mathrm{u}$ domovinu, transnacionalne obitelji, konstrukciju identiteta i diskurse o kulturi potomaka migranata te inkorporaciju migrantske populacije.

Sljedeće poglavlje »Državne ideologije privremenosti: od povratka do transmigracije« produbljuje teme iz 
prvog poglavlja knjige, tj. obrađuje (promjenljive) namjere povratka migranata povezujući ih s državnim politikama Njemačke i tadašnje Jugoslavije koje su poticale povratak i ideju privremenosti migracije. Prema Čapo: »Migranti su interiorizirali postuliranu privremenost svoje migracije, a povratak je i u njihovom zamišljanju postao njezin sastavni dio« (str. 141). Upravo je namjera povratka u pozadini mobilnosti između zemlje primitka i porijekla te ulaganja u domovinu kao ključnih karakteristika transnacionalizacije migrantskih aktivnosti, čiji se ishodi obrađuju u narednim poglavljima. Nakon razmatranja statističkih podataka i drugih izvora koji pokazuju da se značajniji povratak radnih migranata iz Njemačke nije dogodio, autorica kroz dvije migrantske obiteljske priče ilustrira promjenljivost i relativnost namjere povratka u odnosu na klasično koncipirani »povratak « koji podrazumijeva završni korak u migracijskom procesu te $\mathrm{u}$ odnosu na uvriježeni pojam »emigracije« koji podrazumijeva trajno napuštanje zemlje porijekla. Autorica zaključuje da »pojam 'povratak' ne može adekvatno označiti migracijski proces u kojemu se distinkcije između privremenog i trajnog boravišta, emigranata, imigranata i povratnika gube, a odlasci i vraćanja zbivaju (...) u oba smjera « (str. 182).

Glavne su teme petog poglavlja »bilokalnost i dvodomnost«, tj. paralelni angažmani migranata $\mathrm{u}$ mjestima života (lokalno) i porijekla (transnacionalno). Na primjerima migrantskih ulaganja u domovini, a naročito ulaganja u nekretnine, tj. gradnje kuća kao »paradigmatskoj transnacionalnoj aktivnosti hrvatskih ekonomskih mi- granata u Njemačkoj« (str. 186), Čapo obrađuje dvostruki (a u nekim slučajevima i trostruki) životni fokus migranata, dovodeći u pitanje esencijalističko poimanje doma. U drugom dijelu poglavlja autorica razmatra i rodnu perspektivu ulaganja u obnovu ili izgradnju kuće u domovini, tj. razlike između supružnika u poimanju simboličke vrijednosti i emocionalne važnosti kuće u rodnom kraju. Autorica zaključuje da »[ž]ene pridaju veću važnost životu u mjestu u kojemu žive«, dok su muški interesi u većoj mjeri locirani u mjestu porijekla (str. 215), uz napomenu da su rodne razlike odraz konkretnoga migracijskog i obiteljskog trenutka te da ih ne treba esencijalizirati (str. 225).

Sljedeće poglavlje $\gg$ Transnacionalne obitelji: obitelji razdvojene državnim granicama« bavi se transnacionalnim obiteljskim aranžmanima hrvatskih migranata kao posljedicom »rotacijskoga migracijskog režima i (...) novačenja stranih radnika bez članova njihovih obitelji« (str. 230) s pretpostavkom da će se migranti vratiti u zemlju porijekla. Nakon pregleda dostupnih statističkih podataka Jasna Čapo fokusira se na oblike i transformacije transnacionalnih obitelji s naglaskom na transnacionalno roditeljstvo i mobilnost. Na temelju triju migracijskih obiteljskih priča autorica analizira različite karakteristike i dinamiku transnacionalnog roditeljstva, uključujući i ambivalentnost fizičkog okupljanja obitelji. U drugome dijelu poglavlja temu transnacionalnog roditeljstva i spajanja obitelji obrađuje i iz retrospektive (danas odrasle) djece, koja su zbog nedovoljnog poznavanja jezika, kao i roditeljske orijentacije na povratak, često inicijalno imala 
poteškoće u školi i probleme s uklapanjem u njemačko vršnjačko okruženje. Capo zaključuje da »transnacionalna obitelj nije samo prijelazna etapa tipična za određenu migracijsku fazu (...), već (...) može postati dugoročnim načinom života migrantske obitelji« (str. 264).

Sedmo poglavlje »Transnacionalne generacije 'na dvije stolice' i transkulturacija« obrađuje diskurse o kulturi potomaka hrvatskih migranata. Unatoč njihovu životu u multietničkim i multikulturnim gradovima, razgovori koje je Jasna Čapo provela s potomcima hrvatskih migranata »obilovali su raspravama o 'njemačkoj' i 'hrvatskoj' kulturi, o njihovoj bikulturnosti i identitetnim dilemama « (str. 273), $\mathrm{u}$ odnosu na »relevantne etničke druge«, Nijemce ili Hrvate. S druge strane, iako narativno uglavnom preuzimaju esencijalizirani koncept kulture svojstven javnome diskursu, prakse autoričinih mladih sugovornika »ukazuju da kulture nisu fiksni, okamenjeni načini mišljenja i djelovanja već da se kultura mijenja i kreolizira u procesu transkulturacije« (str. 274), kao i da je hrvatska populacija u Njemačkoj kulturno heterogena.

Kao nastavak tema iz prethodnog poglavlja, osmo se poglavlje bavi procesima identifikacije i transnacionalnim praksama potomaka hrvatskih migranata, tj. transnacionalnih generacija. Zahvaljujući boravcima u $\mathrm{Hr}-$ vatskoj i/ili Bosni i Hercegovini, potomci hrvatskih migranata razvili su osjećaje pripadnosti i emocionalne veze s konkretnim mjestima koja su posjećivali, ali i s domovinom u širem smislu. Autorica na četiri primjera podrobnije predstavlja »subjektivne predodžbe i osjećaje pripadnosti« tih mladih osoba (str. 322) te ilustrira heterogenost, nelinearnost i situacijsku promjenljivost identiteta, kao i različite moduse inkorporacije sugovornika u Njemačkoj i Hrvatskoj/Bosni i Hercegovini.

U posljednjem poglavlju »Prema novoj koncepciji hrvatskih radnih migracija u Njemačku« Jasna Čapo kroz kritiku negativnog prikaza "gastarbajterstva« u popularnoj kulturi, ali i nekim etnološkim radovima, sumira glavne nalaze istraživanja. Nasuprot mnogim stereotipima o hrvatskim radnim migracijama $\mathrm{u}$ Njemačku, ali i metodološko nacionalističkoj perspektivi koju kritizira, ova studija prikazuje aktivnu ulogu migranata i njihovih potomaka »pri donošenju i mijenjanju migracijskih odluka i prilagođavanju promjenama strukturnih prilika u obje zemlje koje svojim praksama povezuju « (str. 358).

Knjiga Dva doma predstavlja studiju bogate i logično strukturirane empirijske građe koja sustavno i čitko potkrepljuje autoričine glavne teze o različitim oblicima transnacionalnosti hrvatskih radnih migracija u Njemačku kroz više desetljeća, koje se najčešće analiziraju kroz prizmu promjenjivosti namjere povratka migranata. Uz ostale vrijednosti ova će studija sasvim sigurno ispuniti i jedan od ciljeva koji napominje autorica, tj. pridonijeti obnovljenom zanimanju za hrvatske radne migracije u Njemačku, kako one iz šezdesetih i sedamdesetih godina prošloga stoljeća, koje su glavnim predmetom ove knjige, tako i suvremene.

\section{Simona Kuti}

Institut za migracije i narodnosti, Zagreb 